\title{
ASSOCIATION OF SERUM PARAOXONASE 1 ACTIVITIES, POLYMORPHISMS AND OXIDATIVE STRESS IN BREAST CANCER PATIENTS WITH TYPE 2 DIABETES MELLITUS
}

\author{
VEZA AKTIVNOSTI SERUMSKE PARAOKSONAZE 1, POLIMORFIZMA I OKSIDATIVNOG \\ STRESA KOD PACIJENTKINJA SA RAKOM DOJKE I DIJABETESOM TIP 2 \\ Fatma Ceyla Eraldemir ${ }^{1}$, Nihal Üren ${ }^{2}$, Tuğba Kum ${ }^{1}$, Burcu Erbay ${ }^{3}$, Deniz Şahin $^{4}$, Emel Ergül ${ }^{2}$, \\ Esra Acar ${ }^{1}$, Doğa Özsoy ${ }^{1}$, Mustafa Çekmen ${ }^{5}$, Hale Kır $^{1}$, Zafer Utkan ${ }^{3}$ \\ ${ }^{1}$ Department of Biochemistry, School of Medicine, Kocaeli University, Kocaeli, Turkey \\ ${ }^{2}$ Department of Medical Biology and Genetics, School of Medicine, Kocaeli University, Kocaeli, Turkey \\ ${ }^{3}$ Department of General Surgery, School of Medicine, Kocaeli University, Kocaeli, Turkey \\ ${ }^{4}$ Department of Physiology, School of Medicine, Kocaeli University, Kocaeli, Turkey \\ ${ }^{5}$ Department of Biochemistry, School of Medicine, Medeniyet University, Istanbul, Turkey
}

\section{Summary}

Background: The aim of the study was to investigate the association of paraoxonase 1 (PON1) polymorphism, PON1/ arylesterase (ARE) activity and oxidative stress index (OSI) in breast cancer (BC) patients with type 2 diabetes (DM).

Methods: Our study group consisted of 30 healthy women (HV group) and 66 female $B C$ patients. The $B C$ patients were divided into two groups: those with $(n=37)$ and without DM $(n=29)$ (BDM and NBDM group). Genotyping of PON1 Q192R and L55M polymorphisms were done by polymerase chain reaction (PCR) - restriction fragment length polymorphism (RFLP) method. Serum PON1/ARE enzyme activities, total oxidant status (TOS) and total antioxidant status (TAS) were analysed by spectrophotometric method. The ratio of TOS to TAS was accepted as the oxidative stress index (OSI).

Results: PON1 Q192R genotype frequency distribution was significantly different in the BDM group compared to the NBDM group $(p=0.021)$. When alleles distribution was examined, $R$ and $L$ alleles were significantly lower, $Q$ and $M$ alleles were significantly higher in the BDM group than in the NBDM group $(p<0.001)$. TOS and OSI were statistically higher in $B C$ patients than HV group ( $p<0.001)$.

Conclusions: Our results suggest that $P O N 1$ gene $Q$ and $M$ alleles may be the risk factors predisposing formation of $B C$

\section{Kratak sadržaj}

Uvod: Cilj studije bio je istraživanje veze polimorfizma paraoksonaze 1 (PON1), aktivnosti PON1/arilesteraze (ARE) i indeksa oksidativnog stresa (OSI) kod pacijentkinja sa rakom dojke (BC) i dijabetesom tip 2 (DM).

Metode: Naša studijska grupa se sastojala od 30 zdravih žena (HV grupa) i 66 žena sa rakom dojke (BC). Pacijentkinje iz $\mathrm{BC}$ grupe su podeljene $u$ dve grupe: one sa ( $\mathrm{n}=$ $37)$ i bez DM ( $n=29)$ (BDM i NBDM grupa). Genotipizacija PON1 K192R i L55M polimorfizama vršena je polimeraznom lančanom reakcijom (PCR) - metodom polimorfizma dužine restrikcionih fragmenta (RFLP). Enzimske aktivnosti serumske PON1/ARE, ukupni oksidativni status (TOS) i ukupni antioksidativni status (TAS) analizirani su spektrofotometrijskom metodom. Odnos TOS-a prema TAS-u je prihvaćen kao indeks oksidativnog stresa (OSI).

Rezultati: Frekvencija distribucije genotipova PON1 K192R bila je značajno drugačija u BDM grupi u odnosu na NBDM grupu ( $p=0,021)$. Kada je ispitana alelna distribucija, R i L aleli su bili značajno niži, $\mathrm{K}$ i $M$ aleli su bili značajno viši u BDM grupi nego u NBDM grupi ( $p<$ $0,001)$. TOS i OSI su bili statistički viši kod pacijentkinja sa rakom dojke odnosu na HV grupu ( $p<0,001)$.

Zaključak: Naši rezultati ukazuju na to da PON1 gen Q i M aleli mogu biti faktori rizika koji predisponiraju razvoj raka

\footnotetext{
Address for correspondence:

Dr. Fatma Ceyla Eraldemir M.D.

Department of Biochemistry

School of Medicine, Kocaeli University

41380 Kocaeli, Turkey

Tel: +902623037256

e-mail: ceyeraldemir@gmail
}

List of abbreviations: $\mathrm{BC}$, breast cancer; PON1, paraoxonase 1; ARE, arylesterase; TOS, total oxidant status; TAS, total antioxidant status; OSI, oxidative stress index; HV, healthy volunteers; BDM, breast cancer with type 2 diabetes mellitus; NBDM, breast cancer without type 2 diabetes mellitus. 
due to increased oxidant damage seen in DM. However, these statements require further confirmation with screening PON1 polymorphism in a greater number of patients with DM, and also wide range follow-up studies are necessary for the same purpose.

Keywords: diabetes mellitus type 2, paraoxonase 1, single nucleotide polymorphism, oxidative stress, breast cancer

\section{Introduction}

Breast cancer (BC) has become a worldwide public health problem. In Turkey, BC is the most common tumour between women in all age groups as mentioned in Turkey unified database 2013. In 2010, the American Diabetes Association (ADA) and the American Cancer Society (ACS) had a common opinion that diabetic patients have an increased risk of $B C(1)$.

Progression of type 2 diabetes (DM) may have a critical role in the initiation and progression of carcinogenesis (2). The mechanisms underlying the relationship between $\mathrm{DM}$ and $\mathrm{BC}$ may be based on oxidative stress. Oxidative stress may cause cell transformation process raising the risk of cancer development (3).

Paraoxonase 1 (PON1) and arylesterase (ARE) are high-density lipoprotein (HDL)-bound enzyme system of antioxidants which protect LDL and HDL from oxidation. Lipid peroxides and hydrogen peroxide are neutralised by PON1 (4). PON1 activity is decreased in diabetic patients $(4,5)$.

Polymorphism in PON1 gene leads to amino acid differences in position 192 of PON1 enzyme (4). Additionally, PON1 enzyme has got ARE enzyme activity and that part of the enzyme is nonpolymorphic. It has been reported that ARE activity is a marker of the actual protein concentration, independent of changes in PON1 activity $(6,7)$.

Loss of the protective effect of PON1 may play an important role in increasing susceptibility to genomic damage and modulate progression of $\mathrm{BC}$ causing releasing of some inflammation factors, oxidants and exogenous carcinogens. In addition, there are studies reporting that the activity of PON1 is decreased in DM patients $(6,8)$.

Our aim was to investigate the relationship between PON1 polymorphism, PON1/ARE activity and oxidative stress in patients with $\mathrm{DM}$ and $\mathrm{BC}$. Oxidative stress index was used to determine whether PON1 polymorphism could be used as a preliminary diagnostic marker for BC susceptibility of diabetic patients.

\section{Materials and Methods}

A total of 66 patients with BC who underwent surgery and 30 healthy volunteers (HV group) with no dojke zbog povećanog oksidativnog oštećenja kod DM. Ipak, ovakva tvrdnja zahteva dalju potvrdu skriningom PON1 polimorfizma kod većeg broja pacijentkinja sa DM, a u istu svrhu su potrebne i dodatne studije širokog spektra.

Ključne reči: dijabetes melitus tip 2, paraoksonaza 1, jednonukleotidni polimorfizam, oksidativni stres, rak dojke

family history of $B C$ were enrolled to participate in this study. The patients were divided into two groups: Those with and without DM (BDM and NBDM group). Participants were chosen from those who were referred to General Surgery Departments of our hospital between June 2014 to December 2015. Patients with renal or liver failure were excluded from the study. The patients with a family history of $B C$ and those who underwent chemotherapy or radiotherapy were not included in this study. The study was approved by the Local Ethics Committee (2014/166 KOU KAEK). Informed consents were obtained from all participants in the study.

Fasting venous blood was drawn into blood tubes with clot activator and serum was separated from the cells by centrifugation at $1500 \mathrm{~g}$ for $10 \mathrm{~min}$, and the serum samples were stored at $-80{ }^{\circ} \mathrm{C}$ until PON1 and ARE activities, total oxidant status (TOS) and total antioxidant status (TAS) analyses. Fasting glucose $(\mathrm{mmol} / \mathrm{L})$, low-density lipoprotein-cholesterol $(\mathrm{LDL}-\mathrm{C})(\mathrm{mmol} / \mathrm{L})$, high-density lipoprotein-cholesterol (HDL-C) $(\mathrm{mmol} / \mathrm{L})$, triglyceride $(T G)(\mathrm{mmol} / \mathrm{L})$ were analysed immediately spectrophotometrically by Abbott Architect c8000 clinical chemistry analyser.

PON1 and ARE activities, TOS and TAS were measured using commercially available kits according to manufacturer instructions (Relassay, Gaziantep, Turkey). The ratio of TOS to TAS was accepted as the oxidative stress index (OSI). For calculation, the resulting unit of TAS was converted to $\mu \mathrm{mol} / \mathrm{L}$, and the OSI value was calculated according to the following formula: OSI (arbitrary unit) $=$ TOS $(\mu \mathrm{mol}$ $\mathrm{H}_{2} \mathrm{O}_{2}$ equivalent/L)/TAS ( $\mu$ mol Trolox equivalent/ $L$ ) $(9-11)$.

Blood tubes with potassium ethylene diamine tetraacetic acid (EDTA) is used for $\mathrm{HbA} 1 \mathrm{c}$ and genotyping analysis. HbA1c was analysed immediately with high-performance liquid chromatography (HPLC) by Adams A1c HA-8160 (BIODPC).

Genomic DNA extraction was done from blood lymphocytes with a conventional salting-out method (12). Genotypes were analysed by using the PCR-RFLP method and the primer set used for PON1 55 rs854560 amplification was F: 5'-GAAGAGTGATGTATA GCCCCAG-3' as forward and R: 5'-TTTAATCCAGA GCTAATGAAAGCC-3' as reverse based on Irene et al. with some modifications (Table I) (13). 
Table I The primary sequences for amplifying each SNP for PON1 polymorphisms.

\begin{tabular}{|l|c|c|c|c|c|c|}
\hline SNP & $\begin{array}{c}\text { Reference } \\
\text { SNP ID }\end{array}$ & & $\begin{array}{c}\text { Forward primer } \\
\text { Reverse primer }\end{array}$ & $\begin{array}{c}\text { Annealing } \\
\text { Tm }\left({ }^{\circ} \mathrm{C}\right)\end{array}$ & $\begin{array}{c}\text { Restriction } \\
\text { enzyme }\end{array}$ & $\begin{array}{c}\text { Digest } \\
\text { Tm }\left({ }^{\circ} \mathrm{C}\right)\end{array}$ \\
\hline L55M & rs854560 & $\begin{array}{c}\text { PON1 } \\
55\end{array}$ & $\begin{array}{c}\text { 5'GAAGAGTGATGTATAGCCCCAG3' } \\
\text { 5'TTTAATCCAGAGCTAATGAAAGCC3' }\end{array}$ & 59 & Hsp92II \\
\hline Q192R & rs662 & $\begin{array}{c}\text { PON1 } \\
\text { 192 }\end{array}$ & $\begin{array}{l}\text { 5'TATTGTTGCTGTGGGACCTGAG3' } \\
\text { 5'CACGCTAAACCCAAATACATCTC3' }\end{array}$ & 58 & BspPI \\
\hline
\end{tabular}

Note: PON1: paraoxonase 1, SNP: single nucleotide polymorphism

Genotypes were analysed using the PCR-RFLP method and the primer set used for PON1 192 rs662 amplification was $\mathrm{F}: 5^{\prime}$ TATTGTTGCTGTGGGACC TGAG-3' as forward and R: 5'-CACGCTAAACCCAA ATACATCTC-3' as reverse based on Irene et al. (13) with some modifications (Table I).

Statistical evaluation was performed with IBM SPSS 20.0 (SPSS Inc. Chicago, IL, USA). The normal distribution fitness test was assessed using the Kolmogorov-Smirnov Test. The differences between the groups were determined by parametric one-way analysis of variance (ANOVA) test Tukey's Multiple Comparison Test for numerical variables with normal distribution and by nonparametric Kruskal-Wallis test and Dunn's Multiple Comparison post-hoc test for variables without normal distribution. Chi-squared test was carried out to compare the entire sample. The mean \pm standard deviation was used for variables with normal distribution. The median $\left(25^{\text {th }}\right.$ $75^{\text {th }}$ percentile) was used for variables without normal distribution. The values of the data, with a significance level of $p<0.05$.

\section{Results}

Demographical and laboratory parameters of BC patients and HV group are presented in Table II. TOS and OSI values were found to be higher and statistically significant in $\mathrm{BC}$ patients than $\mathrm{HV}$ group $(p<0.001)$. When PON1 and ARE activities were compared, there was no statistically significant difference between BC patients and HV group ( $p>0.05$ ), but PON1 activity was found to be lower in $B C$ patients than HV group.

Demographical and laboratory parameters of $\mathrm{BDM}$ and NBDM are presented in Table III. Although no statistical significance was observed ( $p>0.05)$, it was seen that serum PON1 activity was lower in BDM than NBDM group. Genotyping and allelic distribution of PON1 L55M polymorphism between BDM and NBDM groups are given in Table IV. According to the results of our study, there was no statistically significant difference in terms of PON1 L55M poly- morphism between BDM and NBDM groups. However, allelic frequencies were found to be significantly higher in the $M$ allele of BDM group than NBDM group, and also significant decrease was found in the $L$ allele frequencies $(p<0.001)$. Genotype and allelic distribution of PON1 Q192R polymorphism between $B D M$ and NBDM is given in Table $V$. The difference of PON1 Q192R polymorphism genotypes was found to be statistically significant between $B D M$ and $\operatorname{NBDM}(p=0.021)$. In BDM group, QQ genotype rate was significantly higher (48.6\%) than NBDM (27.6\%). QR was found to be lower in BDM (48.6\%) than NBDM $(55.2 \%)$. The rate of RR was found to be lower in BDM (2.7\%) than NBDM (17.2\%). While Q allele frequency was statistically higher in $\mathrm{BDM}$ group than NBDM group, but $R$ allele frequency was statistically lower $(p<0.001)$.

Comparison of PON1, ARE activities is given in Figure 1 and comparison of TAS, TOS, OSI measurements is given in Figure 2 for all participants. PON1 activities of each genotype in $\mathrm{BC}$ patients are shown in Figure 1. When compared according to the PON1 Q192R polymorphism, there was no statistically significant difference between the PON1 enzyme activities of $B C$ patients $(p>0.05)$, but the lowest PON1 enzyme activity was observed in patients with the $\mathrm{QQ}$ genotype (mean \pm standard deviation; QQ:120.0 \pm 80.2; QR: $157.0 \pm 84.2$; RR: $191.4 \pm$ 57.5). In the PON1 L55M polymorphism, there was no statistically significant difference between the PON1 enzyme activities of BC patients ( $p>0.05)$, while the lowest PON1 enzyme activity was observed in patients with $M M$ genotype (median $\left(25^{\text {th }}-75^{\text {th }}\right.$ percentile); LL:113.5(83.47-166.50); LM:152.10 (76.84-216.70); MM:84.11). In total, the lowest PON1 enzyme activity was found in individuals with $M M$ genotype and only 4 of $66 \mathrm{BC}$ patients had $M M$ genotype. ARE activities of each genotype in BC patients are shown in Figure 2. When compared according to the PON1 Q192R and PON1 L55M polymorphisms, there was no statistically significant difference between the ARE enzyme activities of BC patients $(p>0.05)$. 
Table II Demographical and laboratory parameters of BC patients and HV group.

\begin{tabular}{|l|c|c|c|}
\hline Feature & BC Patients $(n=66)$ & HV group $(n=30)$ & P \\
\hline Age (years) & $50.48 \pm 9.91$ & $47.67 \pm 12.38$ & 0.236 \\
\hline PON1 activity $(\mathrm{U} / \mathrm{L})$ & $142.90 \pm 86.98$ & $161.00 \pm 99.19$ & 0.464 \\
\hline ARE activity $(\mathrm{U} / \mathrm{L})$ & $227.80 \pm 55.16$ & $232.10 \pm 43.97$ & 0.709 \\
\hline TOS ( $\mu$ mol $\mathrm{H}_{2} \mathrm{O}_{2}$ equivalent/L) & $58.28(39.06-63.22)$ & $5.53 \pm 1.74$ & $<0.001^{*}$ \\
\hline TAS (Trolox equivalent/L) & $0.95 \pm 0.30$ & $1.05 \pm 0.17$ & 0.117 \\
\hline OSI (Arbitrary Unit) & $62.01 \pm 33.25$ & $5.97 \pm 5.33$ & $<0.001$ \\
\hline
\end{tabular}

Note: the differences between the groups were determined by parametric one-way analysis of variance (ANOVA) test Tukey's Multiple Comparison test for numerical variables with normal distribution (Mean \pm Standard Deviation) and by nonparametric Kruskal-Wallis test and Dunn's Multiple Comparison post-hoc test for variables without normal distribution (median $\left(25^{\text {th }}-75^{\text {th }}\right.$ percentile)).

BC: breast cancer; HV: healthy volunteers, *: statistical significance of $p<0.001$

Table III Demographical and laboratory parameters of BDM and NBDM Groups.

\begin{tabular}{|c|c|c|c|}
\hline Feature & $\operatorname{NBDM}(n=29)$ & $\operatorname{BDM}(n=37)$ & $p$ \\
\hline Age (years) & $47.93 \pm 11.29$ & $52.49 \pm 8.28$ & 0.063 \\
\hline PON1 activity (U/L) & $162.50 \pm 93.99$ & $132.90 \pm 86.31$ & 0.189 \\
\hline ARE activity (U/L) & $235.80 \pm 48.77$ & $221.60 \pm 59.60$ & 0.303 \\
\hline TOS ( $\mu \mathrm{mol} \mathrm{H}_{2} \mathrm{O}_{2}$ equivalent/L) & $50.60 \pm 16.66$ & $60.23(52.12-63.01)$ & 0.299 \\
\hline TAS (Trolox equivalent/L) & $0.91 \pm 0.27$ & $1.00 \pm 0.32$ & 0.210 \\
\hline OSI (Arbitrary Unit) & $60.87 \pm 33.65$ & $62.90 \pm 33.38$ & 0.807 \\
\hline HbA1c (\%) & $5.35 \pm 0.33$ & $6.10(5.90-6.55)$ & $<0.001^{*}$ \\
\hline Fasting glucose (mmol/L) & $5.94 \pm 0.53$ & $7.10(6.83 \pm 7.85)$ & $<0.001^{*}$ \\
\hline LDL-C (mmol/L) & $3.28 \pm 1.04$ & $3.43 \pm 0.85$ & 0.513 \\
\hline HDL-C (mmol/L) & $1.27 \pm 0.31$ & $1.14 \pm 0.33$ & 0.126 \\
\hline $\mathrm{TG}(\mathrm{mmol} / \mathrm{L})$ & $1.49 \pm 0.66$ & $1.85 \pm 0.70$ & $0.041 * *$ \\
\hline
\end{tabular}

Note: BDM: breast cancer patients with type 2 diabetes mellitus, NBDM: breast cancer patients without type 2 diabetes mellitus, PON1: paraoxonase 1, ARE: arylesterase TOS: total oxidant status, TAS: total antioxidant status OSI: oxidative stress index LDL-C: low density lipoprotein- cholesterol, HDL-C: high density lipoprotein-cholesterol, TG: triglycerides, the differences between the groups were determined by parametric one-way analysis of variance (ANOVA) test Tukey's Multiple Comparison test for numerical variables with normal distribution (Mean \pm Standard Deviation) and by nonparametric Kruskal-Wallis test and Dunn's Multiple Comparison post-hoc test for variables without normal distribution (median $\left(25^{\text {th }}-75^{\text {th }}\right.$ percentile)), *: statistically significant of $p<0.001, * *$ : statistically significant of $p<0.05$. 
Table IV Genotyping and allelic distribution of PON1 L 55 M polymorphism between BDM and NBDM Groups.

\begin{tabular}{|c|c|c|c|c|c|c|}
\hline \multirow{2}{*}{$\begin{array}{l}\text { PON } 1 \text { L55M } \\
\text { Polymorphisms }\end{array}$} & \multirow{2}{*}{ Genotype } & \multicolumn{2}{|c|}{ Frequency } & \multirow{2}{*}{$\begin{array}{c}\text { Allele } \\
n=132\end{array}$} & \multicolumn{2}{|c|}{ Frequency } \\
\hline & & $n$ & $\%$ & & $n$ & $\%$ \\
\hline \multirow[t]{3}{*}{$\operatorname{NBDM}(n=29)$} & LL & 13 & $44.8 \%$ & L & 41 & $70.6 \%$ \\
\hline & LM & 15 & $51.7 \%$ & M & 17 & $29.4 \%$ \\
\hline & MM & 1 & $3.4 \%$ & & & \\
\hline \multirow[t]{3}{*}{$\operatorname{BDM}(n=37)$} & LL & 12 & $32.4 \%$ & L & 46 & $62.2 \%$ \\
\hline & LM & 22 & $59.5 \%$ & M & 28 & $37.8 \%$ \\
\hline & $M M$ & 3 & $8.1 \%$ & & & \\
\hline$p$ & 0.243 & & & $<0.001$ & & \\
\hline
\end{tabular}

*Note: PON1: paraoxonase 1, BDM: breast cancer patients with type 2 diabetes mellitus, NBDM: breast cancer patients without type 2 diabetes mellitus, chi-squared test was used, *: statistical significance of $p<0.001$.

Table V Genotyping and allelic distribution of PON1 Q192R polymorphism between BDM and NBDM groups.

\begin{tabular}{|c|c|c|c|c|c|c|}
\hline \multirow{2}{*}{$\begin{array}{l}\text { PON 1 Q192R } \\
\text { Polymorphisms }\end{array}$} & \multirow{2}{*}{ Genotype } & \multicolumn{2}{|c|}{ Frequency } & \multirow{2}{*}{$\begin{array}{c}\text { Allele } \\
n=132\end{array}$} & \multicolumn{2}{|c|}{ Frequency } \\
\hline & & $\mathrm{n}$ & $\%$ & & $\mathrm{n}$ & $\%$ \\
\hline \multirow[t]{3}{*}{$\operatorname{NBDM}(n=29)$} & QQ & 8 & $27.6 \%$ & $Q$ & 32 & $55.2 \%$ \\
\hline & QR & 16 & $55.2 \%$ & $\mathrm{R}$ & 26 & $44.8 \%$ \\
\hline & RR & 5 & $17.2 \%$ & & & \\
\hline \multirow[t]{3}{*}{$\operatorname{BDM}(n=37)$} & QQ & 18 & $48.6 \%$ & Q & 54 & $72.9 \%$ \\
\hline & QR & 18 & $48.6 \%$ & $\mathrm{R}$ & 20 & $27.1 \%$ \\
\hline & $\mathrm{RR}$ & 1 & $2.7 \%$ & & & \\
\hline $\mathrm{P}$ & $0.021 * *$ & & & $<0.001$ & & \\
\hline
\end{tabular}

*Note: PON1: paraoxonase 1, BDM: breast cancer patients with type 2 diabetes mellitus, NBDM: breast cancer patients without type 2 diabetes mellitus, chi-squared test was used, *: statistical significance of $p<0.001, * *$ : statistical significance of $p<0.05$.

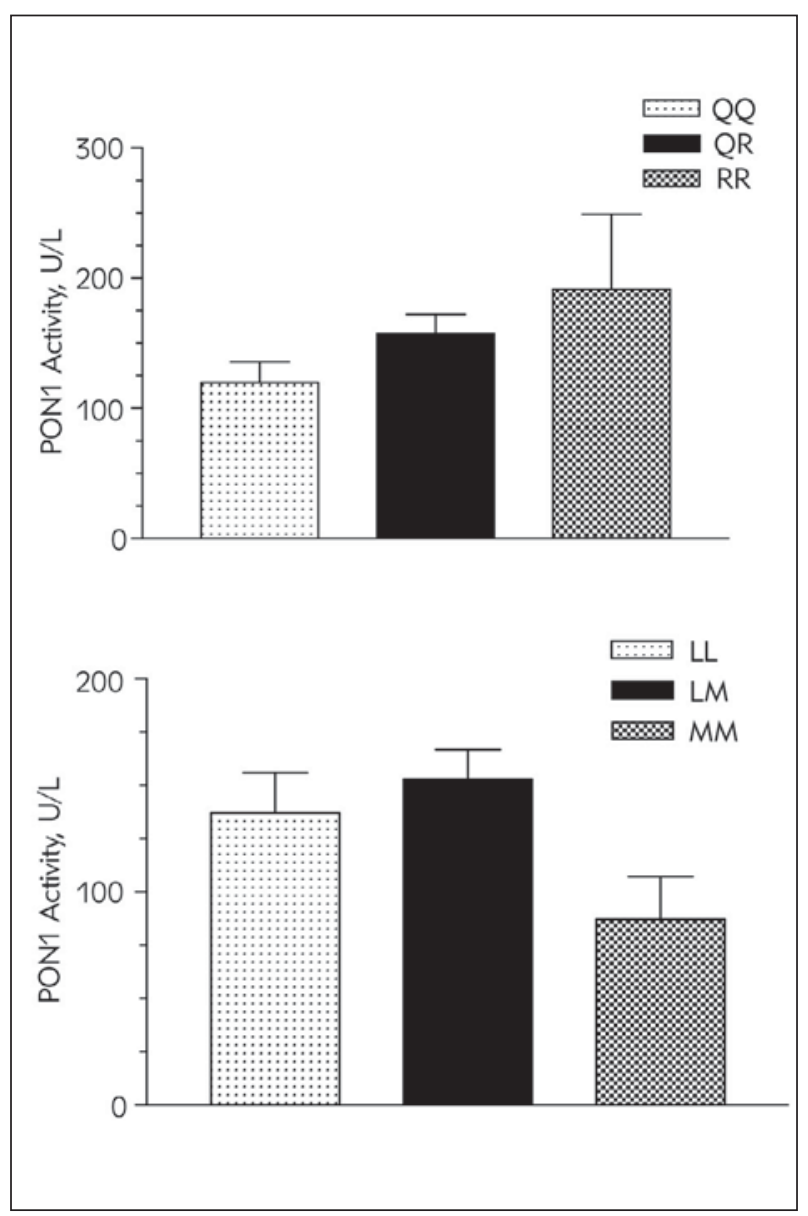

Figure 1 Comparison of paraoxonase 1 (PON1) activity in breast cancer $(\mathrm{BC})$ patients with different genotypes. 


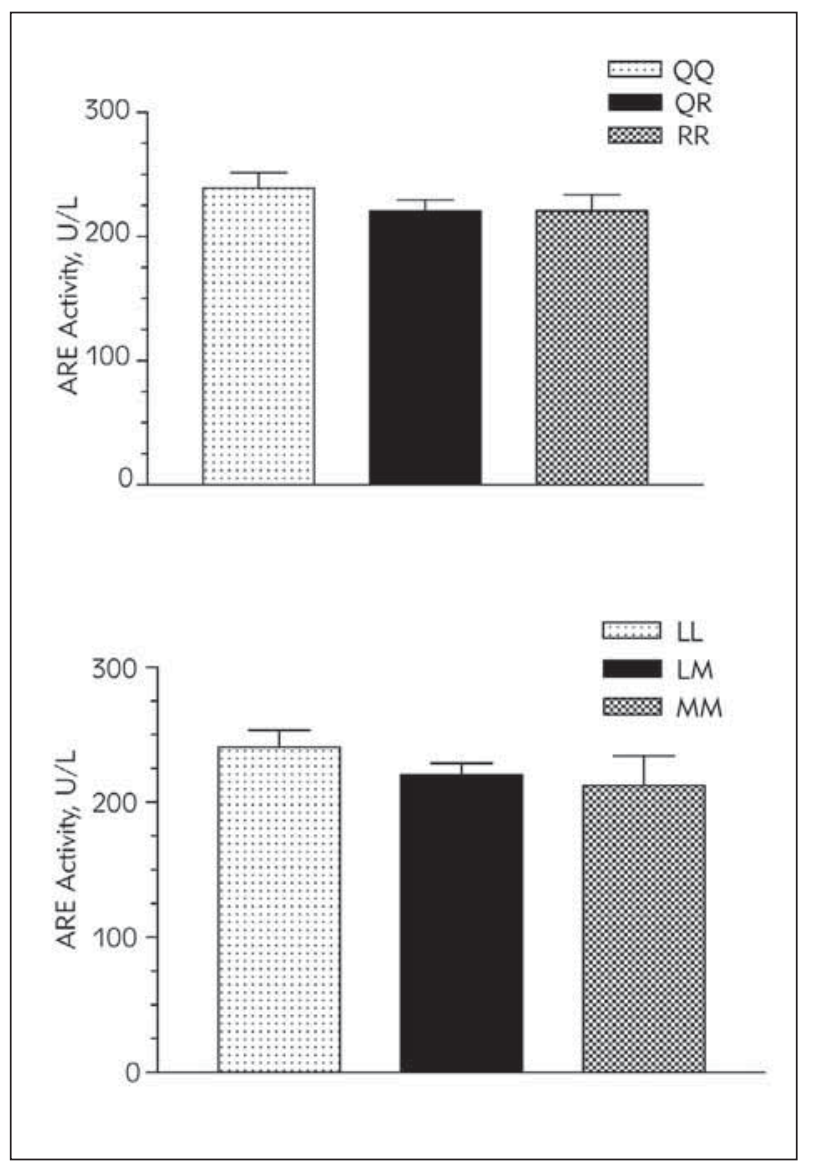

Figure 2 Comparison of arylesterase (ARE) activity in breast cancer (BC) patients with different genotypes.

\section{Discussion}

Epidemiologic evidence suggests that cancer incidence is associated with DM (1). This association was higher for female BC (14). Many epidemiological studies have found a positive association between DM and $B C(15,16)$.

In this study, we examined especially the association between Q192R and L55M polymorphisms of PON1, enzyme activities (PON1 and ARE) and oxidative stress in BDM. These patients were investigated for any difference in their polymorphism, enzyme activity (PON1 and ARE) and oxidative stress from NBDM. At the same time, we wanted to discuss the polymorphism that could lead to $B C$ development in patients with $\operatorname{DM}(17,18)$.

According to the results of this study, TOS and OSI values were found to be higher in all patients comparing to the HV group, and it was statistically significant $(p<0.05)$. When BDM and NBDM groups were compared, TOS and OSI were higher in BDM, but it was not statistically significant. When PON1 polymorphism was evaluated, $\mathrm{QQ}$ genotype ratio, $\mathrm{Q}$ and $M$ allele frequencies were significantly higher in BDM group.
On the other hand, when PON1 activity and genotype association was evaluated in $B C$ patients, it was found that $\mathrm{QQ}$ and $M M$ genotypes have the lowest enzyme activity. Oxidative stress is a condition caused by the inadequate neutralisation of reactive oxygen species (ROS) with antioxidants. Nondetoxified ROS react with lipids, proteins and DNA in the cell damaging the cell structure by abnormal products, causing cell death or DNA damage which, if left unrepaired, may causes cells to become cancerous (16). Both DM and BC are diseases accompanied by increased oxidative stress (3).

Our results showed that OSI was significantly higher in both BDM and NBDM than HV group. There was no statistically significant difference in oxidative stress between patients within groups, and all these findings are consistent with the literature. However, OSI is a little higher in BDM than NBDM. OSI shows a balance between all oxidants and antioxidants existing in the body. Increased OSI means that balance shifts in favour of oxidants.

Advanced glycation end products (AGEs) occur by hyperglycemia in DM. AGEs are responsible for the formation of ROS in this disease. Increased oxidative stress is one of the causative factors in carcinogenesis. Therefore, DM may cause the initiation and progression of carcinogenesis (3).

In $\mathrm{BC}$ patients, we also observed a significant increase in oxidative stress compared to HV group in this study. In BDM group the increase in oxidative stress might have originated from DM and might have triggered $\mathrm{BC}$.

While PON1 and ARE activity was lower in BC patients than HV group in BDM group, it was also lower than NBDM group, but it is not statistically significant. This decline supports oxidative stress elevation. Our results are in consistency with the results of Gupta and his colleagues (19) who reported that the antioxidant activities of PON1 and ARE are low in patients with DM and they suggested that these situations could lead to increased lipid peroxidation. PON1 is a multifunctional enzyme with paraoxonase and arylesterase activities. The activity of PON1 is influenced by various Single nucleotide polymorphisms (20). But ARE activity is not influenced by PON1 polymorphisms (19).

In our study, it was determined that QQ genotype ratio and $\mathrm{Q}$ allele frequency of $\mathrm{BDM}$ group were significantly higher than NBDM group. Although it is not statistically significant, it is remarkable to note that actually there is an association between genotypes and PON1 activities in BC patients. PON1 activity of $B C$ patients with $\mathrm{QQ}$ genotypes was lower, but it was not statistically significant compared with $\mathrm{QR}$ and RR genotypes. Because we observed that PON1 activity is lower in DM patients carrying QQ 
genotype we suppose that this explains the reason for lower PON1 activity.

Memişoğulları and his colleagues (7) found that people with homozygous QQ genotype had a higher risk of $\mathrm{BC}$ than $\mathrm{QR}$ and $\mathrm{RR}$ genotypes. In addition, when the $\mathrm{Q}$ allele is found to be homozygous, it has been shown that it causes an increased BC risk (7).

A meta-analysis study also showed that PON1 M and $\mathrm{Q}$ alleles are associated with a higher risk of $\mathrm{BC}$. Individuals having $M M$ and $\mathrm{QQ}$ genotypes have a lower level and lower detoxification activity of the PON1 enzyme (21). Another meta-analysis study determined that the frequencies of $M$ allele of PON1 gene were associated with the incidence risk of $\mathrm{BC}$ (22).

In our study, we also evaluated PON1 L55M polymorphism, and there was not a statistically significant difference in polymorphism between BDM and NBDM groups. However, LM (59.5\%) and MM (8.1\%) genotype rates were higher in BDM group. There was no statistically significant difference in PON1 enzyme activities among BDM and NBDM groups, but PON1 enzyme activity was found to be low in MM genotype patients. In addition, only 4 of 66 patients were found to have $M M$ genotype. Significantly different allele frequencies were found in $\mathrm{BDM}$ group. The presence of $M M$ and $\mathrm{QQ}$ genotypes was accompanied by lower PON1 activity than of LL and RR genotypes. $M$ and $Q$ alleles had lower activity of the PON1 enzyme. PON1 activity of LM genotypes was higher than $M M$ genotypes while it was lower than LL genotypes. On the other hand, it is suggested that the R allele may lead to the production of PON1 enzyme with higher detoxification activity against

\section{References}

1. Giovannucci E, Harlan DM, Archer MC, Bergenstal RM, Gapstur SM, Habel LA, et al. Diabetes and cancer: a consensus report. Diabetes Care 2010; 33(7): 1674-85.

2. Hope C, Robertshaw A, Cheung KL, Idris I, English E. Relationship between $\mathrm{HbA} 1 \mathrm{c}$ and cancer in people with or without diabetes: a systematic review. Diabet Med 2016; 33(8): 1013-25.

3. Cignarelli A, Genchi VA, Caruso I, Natalicchio A, Perrini S, Laviola $L$, et al. Diabetes and cancer: pathophysiological fundamentals of a 'dangerous affair'. Diabetes Res Clin Pract 2018 Apr 18. doi: 10.1016/j.diabres. 2018.04.002.

4. Moya C, Máñez S. Paraoxonases: Metabolic role and pharmacological projection. Naunyn Schmiedebergs Arch Pharmacol 2018; 391(4): 349-359. doi: 10.1007/s00210-018-1473-9.

5. Crow JA, Meek EC, Wills RW, Chambers JE. A casecontrol study. The association of serum paraoxonase 1 potentially carcinogenic products of oxidative stress and lipid peroxidation. This situation may increase the vulnerability of the breast to genetic damage by reducing the ability to neutralise inflammatory oxidants as well as dietary carcinogens.

Because we found that $Q$ and $M$ allele frequencies are significantly higher in BDM group, we think that it may be useful to do PON1 L55M and Q192R polymorphism screening in diabetic patients. In clinical practice, it should be kept in mind that diabetic patients who are carrying $\mathrm{Q}$ and $\mathrm{M}$ alleles may have greater risk to develop BC. But this statement needs to be confirmed by larger study groups in order to prove that PON1 polymorphism will be used as a marker in the future.

\section{Funding}

This work was supported by KOU individual research Project unit (Project number: 2014/099HD).

\section{Ethical approval}

All procedures performed in this study involving human participants were in accordance with the ethical standards of the institutional and/or national research committee and with the 1964 Helsinki Declaration and its later amendments or comparable ethical standards.

\section{Conflict of interest statement} authors.

There is no conflict of interest among the activity and concentration with the development of type 2 diabetes mellitus. Diabetes Metab Res Rev 2018; 34 (3). doi: 10.1002/dmrr.2967.

6. Arenas M, Rodríguez E, Sahebkar A, Sabater S, Rizo D, Pallisé $O$, et al. Paraoxonase-1 activity in patients with cancer: A systematic review and meta-analysis. Crit Rev Oncol Hematol 2018; 127: 6-14. doi: 10.1016/ j.critrevonc.

7. Memişoğulları R, Osto Orhan N. Paraoksonaz ve Kanser. Konuralp Tıp Dergisi 2010; 2(2): 22-26.

8. Wu J, Fang M, Zhou X, Zhu B, Yang Z. Paraoxonase 1 gene polymorphisms are associated with an increased risk of breast cancer in a population of Chinese women. Oncotarget 2017; 8(15): 25362-71.

9. Yumru M, Savas HA, Kalenderoglu A, Bulut M, Celik H, Erel O. Oxidative imbalance in bipolar disorder subtypes: a comparative study. Prog Neuropsychopharmacol Biol Psychiatry 2009; 3(6): 1070-4. 
10. Kosecik M, Erel O, Sevinc E, Selek S. Increased oxidative stress in children exposed to passive smoking. Int J Cardiol 2005; 100(1): 61-4.

11. Harma $M$, Harma $M$, Erel O. Increased oxidative stress in patients with hydatidiform mole. Swiss Med Wkly 2003; 133(41-42): 563-6.

12. Miller SA, Dykes DD, Polesky HF. A simple salting out procedure for extracting DNA from human nucleated cells. Nucleic Acids Res 1988; 16(3): 1215.

13. Irene MR, Pascal PM, Dorothy McMaster, lan S. Young, Chris Patterson, Maurice J. Savage, et al. Paraoxonase polymorphisms PON1 192 and 55 and longevity in Italian centenarians and Irish nonagenarians. A pooled analysis. Exp Gerontol 2004; 39(4): 629-35.

14. Gini A, Bidoli E, Zanier L, Clagnan E, Zanette G, Gobbato $M$, et al. Cancer among patients with type 2 diabetes mellitus: A population-based cohort study in northeastern Italy. Cancer Epidemiol 2016 Apr; 41: 807. doi: 10.1016/j.canep.2016.01.011

15. Boyle P, Boniol M, Koechlin A, Robertson C, Valentini F, Coppens $K$, et al. Diabetes and breast cancer risk: a meta-analysis. Br J Cancer 2012; 107(9): 1608-17.

16. Gupta RK, Patel AK, Shah N, Chaudhary AK, Jha UK, Yadav UC, et al. Oxidative stress and antioxidants in disease and cancer: a review. Asian Pac J Cancer Prev 2014; 15(11): 4405-9.
17. Ünüvar S, Tanrıverdi Z, Aslanhan H. Potential Prognostic Role of immune system activation marker neopterin in patients with type 2 diabetes. J Med Biochem 2018; 37: 465-9.

18. Demirsoy HI, Ertural YD, Balci Ş, Çınkır Ü, Sezer K, Tamer L, Aras N. Profiles of circulating miRNAs following metformin treatment in patients with type 2 diabetes. J Med Biochem 2018; 37: 499-506.

19. Gupta N, Binukumar BK, Singh S, Sunkaria A, Kandimalla R, Bhansali A, et al. Serum paraoxonase 1 (PON1) activities (PONase/AREase) and polymorphisms in patients with type 2 diabetes mellitus in a North-West Indian population. Gene 2011; 487(1): 88-95.

20. Shakeri R, Khajeniazi S, Marjani A. Association between promoter polymorphism $(-108 \mathrm{C}>\mathrm{T})$ of paraoxonase 1 gene and it's paraoxonase activity in patients with Type 2 diabetes in northern Iran. Clin Chim Acta 2017 Nov; 474: 34-7. doi: 10.1016/j.cca.2017.08.037.

21. Mostafa S. Paraoxonase 1 genetic polymorphisms and susceptibility to breast cancer: A meta-analysis. Cancer Epidemiology 2012; 36(2): 101-3.

22. Wen Y, Huang Z, Zhang X, Gao B, He Y. Correlation between PON1 gene polymorphisms and breast cancer risk: a Meta-analysis. Int J Clin Exp Med 2015; 8(11): 20343-8. 